\title{
How is COVID-19 Experience Transforming Sustainability Requirements of Residential Buildings? A Review
}

\author{
Galym Tokazhanov ${ }^{1,+} \oplus^{\oplus}$, Aidana Tleuken ${ }^{1,+}$, Mert Guney ${ }^{1,2}{ }^{\circledR}$, Ali Turkyilmaz ${ }^{1,3}$ and \\ Ferhat Karaca $1,2, *$ (1) \\ 1 Department of Civil and Environmental Engineering, Nazarbayev University, Nur-Sultan 010000, \\ Kazakhstan; galym.tokazhanov@nu.edu.kz (G.T.); aidana.tleuken@nu.edu.kz (A.T.); \\ mert.guney@nu.edu.kz (M.G.); ali.turkyilmaz@nu.edu.kz (A.T.) \\ 2 The Environment and Resource Efficiency Cluster (EREC), Nazarbayev University, \\ Nur-Sultan 010000, Kazakhstan \\ 3 Master of Engineering Management Program, Nazarbayev University, Nur-Sultan 010000, Kazakhstan \\ * Correspondence: ferhat.karaca@nu.edu.kz; Tel.: +7-7172-704553; Fax: +7-7172-706054 \\ + Co-first authors: These authors have equally contributed to the manuscript.
}

Received: 26 September 2020; Accepted: 17 October 2020; Published: 21 October 2020

\begin{abstract}
The COVID-19 pandemic is bringing about changes, and alongside these, we can alter the way we design our living spaces. The need for a healthy and comfortable living space is essential to mental and physical well-being. The present study covers the most up-to-date documents, including peer-reviewed papers, blog posts, news, journal articles, and expert opinions, to critically review lessons learned from the COVID-19 pandemic and evaluates the expected changes in sustainability requirements of residential buildings. Health and safety, environment, and comfort are the three main aspects of residential buildings that have been tested during quarantines and are also expected to experience major transformations toward sustainability. Residential houses should provide certain health and safety protective measures to their occupants, such as the application of new touchless technologies, having proper sanitation to diminish the probability of getting infected, and developing greener and more intimate spaces that can help recover and improve mental states. Our findings address the need to reconsider sustainability requirements for residential buildings, which will provide adequate health and safety and comfort with no significant harm to the environment.
\end{abstract}

Keywords: COVID-19 pandemic; housing; residential buildings; SARS-CoV-2; sustainability requirements

\section{Introduction}

December 2019 marked the beginning of a novel disease outbreak, later called COVID-19 by the World Health Organization (WHO) [1]. Epidemiological links led the virus origins to animal stock in Wuhan [2]. Taking into account that some previous disease outbreaks have also been zoonotic (originating from animals), such as SARS (Severe Acute Respiratory Syndrome) in 2003 and MERS (Middle East Respiratory Syndrome) in 2012, researchers claim that the amount of novel zoonotic diseases is expected to rise in the future [2,3]. For instance, markets that sell meat and products from wild animals are still not prohibited and thus continue to exist globally. This indicates a still ongoing threat of new disease outbreaks of animal origin. In addition, some researchers forecast a rise of zoonotic diseases, linking them to climate change and extensive land usage for agriculture and construction of infrastructure, as these activities put stress on the wildlife by reducing their habitat zones [3]. Finally, existing land-use practices lead habitats of humans and domestic animals to be 
brought closer to wild animals, which eases the way of virus mixing and further propagation [2]. COVID-19, caused by SARS-CoV-2, has progressed to become a global pandemic, and, in contrast to previous pandemics, it caused a global-scale crisis in medical systems and business [1]. The COVID-19 pandemic has so far created a tremendous impact on humanity's both personal and professional aspects.

Possible means of contagion propagation and their lifespan in different mediums are still being researched. Recent studies show that one of the transmission means is air in human-to-human interaction, and SARS-CoV-2 is able to suspend in the air for up to four hours [4]. Another means of propagation is to deposition the virus on the surfaces after direct contact with an infected person or indirectly via turbulent flow. The lifespan depends on the medium matter, e.g., steel surfaces allow the virus to survive up to three days $[4,5]$.

In a short time, rapidly propagating COVID-19 has forced people to spend most of their time at home to prevent the risk of viral spread [5]. The world needs to adapt quickly to such changes in lifestyle and to bear with strict safety measures. Remembering recent outbreaks of other diseases, COVID-19 is another vivid reminder of the danger of unknown diseases uprising [2]. The experience of quarantine life due to the COVID-19 pandemic continues to transform the perception of the environment in different ways. Dense spaces will no longer be as welcomed, as they increase virus transmission routes. As such, to improve social distancing, public spaces have been (and are still) suspended worldwide.

In addition to the impacts detailed above, offices, universities, and schools remain closed in some locations, necessitating people to work and study from home [6]. Therefore, residential buildings have become a crucial infrastructure type, vital for sustaining these disrupted communities [5]. Housing is becoming more than just a living space, which also significantly increases buildings' resource consumption (e.g., electricity and water). Therefore, even with the relief of the COVID-19 pandemic, the current world we live in still needs to acquire changes to become more resilient to possible upcoming disease outbreaks and lockdowns, and it introduces challenges to the existing residential buildings for adaptation to a new reality. To ensure that we remain resilient and sustainable, future houses need to be able to answer questions under epidemic measures, such as (1) how to effectively avoid disease propagation, (2) how to minimize the environmental effect, and (3) how to maintain and improve the comfort of people spending most of their time at home.

\section{Impact of COVID-19 on General Society and Urban Environment}

Before COVID-19, various other diseases have shaped our environment, including city planning and residence interiors, and there were several developments in architecture and urbanization in the last two centuries. Historically, the bubonic plague that happened in the 14th century facilitated the urban development of the Renaissance. More recently, the 20th century's challenges, including overcrowded cities with tuberculosis and various flu types, motivated architects and urbanists of that time to make changes such as clearance of slums, reforms of tenements, and waste management. As another example, smooth, straight, and wide streets for proper underground pipe system installation were developed due to cholera and typhoid outbreaks during the industrial era [7]. Recently, COVID-19 has drawn many researchers' attention from various fields and thus become one of the most frequently studied topics. The previous studies mainly discussed how COVID-19 influenced multiple aspects of our life, including economic factors [8], sustainable development goals [9,10], food pathways [11], education [12], tourism [13], urbanization [7], living spaces [14], and business [10].

Filho et al. [9] reported that COVID-19's economic impacts are unexamined and only going to unfold; the global economic downswing is estimated to be more challenging than the financial crisis of 2007-2009. According to the United Nations Trade and Development Agency (UNCTAD) [14], the consequences of COVID-19 are going to cost the global economy in 2020 around one trillion USD, considering that the length of the pandemic is ambiguous. Consequently, a global economic collapse is expected to have harsh consequences, including food shortages and hunger. Blay-Palmer et al. [11] stated that the right to food should be guaranteed under international law to fulfill the obligations of all governmental levels. New policies tackling the food shortage and hunger should be based on a 
clear understanding and consideration of the human right to food. Tran et al. (2020) [12] examined the impact of the COVID-19 experience on Vietnamese students' education. The study concluded that there is a significant difference in students' learning routines from different types of schools. Learning capabilities, motivation, and self-discipline play crucial roles in distant learning during the pandemic. Additionally, family income partially influences the efficiency of students' learning in pandemic conditions such that above-average income group students spent less time in offline learning compared to their other peers.

Regarding the impact of the pandemic on business, compared to the Great Depression or the housing recession in national economies (2008), the significant difference of COVID-19 is that it influenced both the supply and the demand side of the economy. Future business is going to be significantly more digitalized, which will bring positive changes, including cost-cutting, increased business intelligence, and more transparency [10]. Digital transformations are expected to occur in all daily activities. Apart from the digitalization of business, most employees have to be ready to host online meetings and to work with new portable types of equipment for virtual communication [15].

It is expected that the COVID-19 pandemic experience will slow down urbanization. Villages and city suburbs will likely gain more attention to be enhanced and experience necessary digital transformations. Moreover, cities are advised to expand horizontally and decrease their densities. Various services, including health facilities, schools, and shopping malls, are better if they are decentralized, putting more attention on smaller units. Urban farming will likely be one of the critical aspects of creating a self-sustaining community $[7,8,16,17]$. Additionally, cities are expected to transform from car-driven to more walkable and cyclable, which is advantageous over cars by being environmentally friendly as well as beneficial for the physical and mental health of citizens $[18,19]$. Office spaces are also expected to experience necessary changes, with larger spaces having fewer seats, to ensure the new requirements of social distancing $[20,21]$.

The COVID-19 pandemic experience will also influence strategies for building construction. Modular construction will gain more popularity, because it allows the construction of various building types quickly with lower expenses [22]. Standardized prefabricated components of modular construction strategy will allow us to adapt to and meet healthcare buildings' requirements during quarantine times [23]. Adaptive reuse of existing structures is one of the possible ways to meet the demands for emergency facilities. In case of a sudden pandemic, big spaces such as sports facilities and fields, parking lots, and other open space buildings could be converted into temporary medical facilities or hospitals. Future buildings will be designed considering the opportunity for efficient, flexible, and quick transformation of the building for necessary needs (hospitals, medical facilities, etc.) [24]. Lightweight and adaptable structures have advantages such as construction speed and portability. Temporary structures that can be easily disassembled and transported as field hospitals are being designed for use during COVID-19-like pandemics [24,25]. Post-pandemic architecture may also include hygienic building materials that are easy to be sanitized $[20,26]$.

Apart from the impacts in general society and the urban environment, as mentioned above, a new set of requirements and suggestions are emerging regarding building design. This suggests a drastic paradigm change from "business as usual" to "for a pandemic" in the design and operation of buildings, particularly for residential buildings. The building design will experience various changes starting from general construction methods to the planning of its details [27,28]. Megahed and Ghoneim [7] highlighted some significant changes that are expected to happen in future architecture approaches, promoting self-sufficient strategies and refocusing on green space and low-rise buildings with better indoor air quality. An autonomous design of a building is especially crucial during pandemic conditions when the transportation of food and other goods are limited [29,30]. While interaction with green spaces positively influences people's mental health and allows them to grow food during self-isolation time, at the same time, low-rise buildings and resulting better air quality will enable the reduction of density of people as well as the risks of being self-isolated for long durations [31]. Assuming that future buildings are going to experience various transformations, the set of new standards and the 
design process of new buildings will require a multidisciplinary approach [32]. Significant changes that are going to happen in the design of buildings include greener spaces [13], better air ventilation and intimacy [33], improved water and wastewater management [34], introduction of touchless technologies and antimicrobial materials [35], better solid-waste management [36], social distancing within the house [31], and lightweight architecture and flexible building design [37].

The COVID-19 pandemic forced authorities to oblige people to stay home for disease propagation prevention in many locations. This has abruptly disturbed professional and personal lifestyles all over the world. This leads to the fact that, from now on, homes will be more than just a living place. Consequently, the coronavirus pandemic leads to a reconsideration of existing buildings, which need to become more resilient and sustainable for other possible upcoming disease epidemics/pandemics. The present work aims to define the current sustainability limitations of residential buildings in providing a resilient response to disease outbreaks, and it reviews the emerging solutions and ideas that will lead to "design for a pandemic". The present work addresses the following research questions: (1) how to assess the capacity of existing buildings to protect occupants' health and safety, especially during lockdown periods; (2) evaluating the effect of pandemics on residential buildings' resources consumption; (3) defining the deficiencies of current residential buildings in terms of bringing comfort to the occupants; and (4) addressing emerging solutions and ideas for residential building design that will shift the design paradigm from "business as usual" to "for a pandemic".

\section{Search Methodology and Data Collection}

The method of data and information collection for the present study was based on a state-of-the-art review [38] of the rapidly growing literature on COVID-19. The speed of information and data flow related to COVID-19 is extraordinary such that an example of such rapidly growing literature on a particular subject has never been previously witnessed. That guided us to a process such that the relevant information was not only collected from scientific literature but also from various high-quality online resources, including blogs, journals, news, policy, and media reports. The available literature was collected from March 2020 (the start of the COVID-19 Pandemic) until the completion of the present manuscript (September 2020). The primary source groups of the study (summarized in Table 1) and the data collection/review were focused on two main categories: (a) lessons learned from the COVID-19 pandemic experience; and (b) its impact on the design of residential buildings. The literature review for the first category mainly focused on the information from Central Asia (which is our expertise area regarding building sustainability), with most findings widely applicable and generalizable to the global context, whereas the second category considered the available information from all around the world. Google and Nazarbayev University Library (with a subscription to 249 databases including ScienceDirect, PubMed, Scopus, and Web of Science) were used as search platforms with some of the keywords used (used individually as well as in combination) including "Effect of COVID-19 pandemic", "Water consumption", “Energy consumption", "Domestic violence", "Central Asia", "Personal comfort during lockdown", "Waste management", "Sustainability of residential buildings", and "Sustainability requirements". 
Table 1. Summary of literature review, sources, and information.

\begin{tabular}{|c|c|c|c|c|c|}
\hline $\begin{array}{l}\text { Data/Knowledge } \\
\text { Source }\end{array}$ & Type of Information & Database/Source & $\begin{array}{l}\text { Literature } \\
\text { Found }\end{array}$ & Subtotal & Total \\
\hline \multirow{3}{*}{$\begin{array}{c}\text { Nazarbayev } \\
\text { University Library }\end{array}$} & \multirow{3}{*}{ Peer-reviewed research papers } & ScienceDirect & 13 & \multirow{5}{*}{51} & \multirow{11}{*}{119} \\
\hline & & PubMed & 25 & & \\
\hline & & Others & 4 & & \\
\hline \multirow{8}{*}{ Google } & \multirow{2}{*}{ Peer-reviewed research papers } & MDPI & 5 & & \\
\hline & & Others & 4 & & \\
\hline & \multirow{2}{*}{ Policy reports } & $\mathrm{UN}$ & 6 & \multirow[b]{2}{*}{8} & \\
\hline & & WHO & 2 & & \\
\hline & \multicolumn{2}{|c|}{ Other reports } & 6 & \multirow{4}{*}{60} & \\
\hline & \multicolumn{2}{|l|}{ News } & 19 & & \\
\hline & \multicolumn{2}{|c|}{ Blogs and Journals } & 34 & & \\
\hline & \multicolumn{2}{|l|}{ Books } & 1 & & \\
\hline
\end{tabular}

\section{Residential Building Sustainability Lessons Learned from COVID-19}

The COVID-19 experience has revealed certain deficiencies in current residential building design such that living conditions should be rethought and improved for better resilience through pandemics. More than $90 \%$ of infected cases happened in cities, as they have a significant amount of dense and concentrated places [39]. Since multi-story housing is standard in most cities, they need special attention. The sustainability lessons for residential buildings (summarized in Table 2) are presented below as categorized into the following perspectives: (1) health and safety, (2) environment, and (3) comfort.

Table 2. Summary of sustainability lessons learned regarding residential buildings from COVID-19.

\begin{tabular}{|c|c|c|c|}
\hline Category & Subcategory & Problems & References \\
\hline \multirow[t]{3}{*}{ Health \& Safety } & Virus propagation risks & $\begin{array}{c}\text { Existing residential buildings have many surfaces of contact } \\
\text { (e.g., elevators, doors, ladders), which leads to limited } \\
\text { capacity to protect the occupants from virus transmission } \\
\text { through surfaces and by air. }\end{array}$ & [13] \\
\hline & Domestic violence threat & $\begin{array}{l}\text { Lockdowns tend to increase domestic violence frequency, and } \\
\text { most existing residential buildings lack any service or facility } \\
\text { that could help the victims. }\end{array}$ & [40-44] \\
\hline & General health risks & $\begin{array}{c}\text { Housings that lack proper comfort can lead to a decline in } \\
\text { both physical and psychological health. }\end{array}$ & [45] \\
\hline \multirow{5}{*}{ Environment } & Energy & $\begin{array}{l}\text { Increased energy usage due to global lockdowns (e.g., cooking, } \\
\text { the use of ICTs, laundry, entertainment) creates a greater and } \\
\text { uninterrupted need for sustainable energy sources. }\end{array}$ & [46-49] \\
\hline & Waste & $\begin{array}{c}\text { Households are not ready to manage the possibly infected } \\
\text { waste; therefore, there is an emerging need to create a waste } \\
\text { separation and disinfection strategy. }\end{array}$ & {$[50,51]$} \\
\hline & & $\begin{array}{l}\text { Increased water consumption due to lockdowns might lead to } \\
\text { water shortages. It drives a larger necessity for sustainable }\end{array}$ & \\
\hline & Water & water management. & [52-54] \\
\hline & & $\begin{array}{l}\text { Wastewater needs to be treated appropriately and sanitized to } \\
\text { diminish virus spread. }\end{array}$ & \\
\hline \multirow[t]{3}{*}{ Comfort } & Personal comfort & $\begin{array}{c}\text { Households lacking comfort (personal space, outdoor space) } \\
\text { complicate occupants' lives and lead to health problems } \\
\text { (including mental health). Unavailable ICTs lead to a deficient } \\
\text { use of necessary services (e.g., medical consultation, } \\
\text { food/medicines delivery). }\end{array}$ & {$[39,45,55,56]$} \\
\hline & Living costs & $\begin{array}{l}\text { Due to a sudden drop in economic activity during lockdowns, } \\
\text { paying for increasing housing costs becomes problematic for } \\
\text { several population classes. }\end{array}$ & {$[39,57,58]$} \\
\hline & Local services & $\begin{array}{c}\text { Lack of independent local stores and pharmacies might create } \\
\text { a crisis during lockdowns due to an insufficient amount of } \\
\text { necessary reserves in food and medicines. }\end{array}$ & {$[11,59]$} \\
\hline
\end{tabular}




\subsection{Health and Safety}

The global mortality rate due to COVID-19 is about $3 \%$, according to the latest statistics [60]. The present section discusses how the experience of the coronavirus pandemic may affect the rethinking of residential buildings responding to (1) virus propagation risks and (2) domestic violence threat, which is strongly relatable to the Sustainable Development Goal (SDG) \#3-Health and Wellbeing [61].

\subsubsection{Virus Propagation Risks}

Safety is the prior requirement of a building design. Through the prism of pandemics, it is essential to provide the necessary means of protection from infections inside housing, owing to the fact that most places mandate that people coming from abroad usually undergo a two-week home quarantine [62]. However, most of the current building stocks are not ready to protect the occupants during the disease outbreak. Buildings are full of elements frequently contacted by numerous occupants [13]. In some countries, whole residential complexes had to be isolated in the cases of having infected inhabitants, as one person could infect many other occupants directly by air and indirectly by surfaces (door, elevator, ladders, etc.). For example, in Nur-Sultan, Kazakhstan, several residential complexes had to be put into quarantine, and occupants were forbidden to exit from the buildings [63]. In Aktau, Kazakhstan, there was one case of welding the building's entrance door, and a resident broke his spine while trying to escape [64]. As expected, the residents were highly dissatisfied with the practice of locking down whole multi-story complexes: some occupants needed special medical treatment, which was absent in local pharmacies, and at the same time, local stores did not have sufficient food reserves for all the occupants [59]. This and other similar experiences prove that most current residential facilities are not ready at all for epidemics, as they have (1) a limited capacity to prevent virus transmission and (2) a lack of self-sufficiency for extended periods of isolation.

\subsubsection{Domestic Violence Threat}

One of the expected safety services of buildings is to protect people suffering from domestic violence. There is evidence that lockdowns could evoke stress and anger [40]. Quarantine confinement is argued to lead to more brutal domestic abuse practices all over the world [44]. Increased alcohol sales during quarantine times may also have added up to the increases in domestic violence cases [40]. Restricted from moving, many victims find themselves stuck with their abusers. For example, statistics in Central Asia indicate that domestic violence had a significant rise during the quarantine times, including in Kazakhstan [41], Kyrgyzstan [42], and Uzbekistan [43]. Unfortunately, current residential facilities are also not capable of providing any help to the victims, e.g., they lack built-in emergency shelters, and WHO strongly recommends developing post-pandemic policies that involve designing services able to help domestic violence victims [65]. The design for buildings with better resilience to pandemics should consider ways of helping domestic violence victims.

\subsubsection{General Health Risks}

Housing that lacks proper comfort can lead to a decline in both physical and psychological health. People who have adequate space for work, study, exercise, and personal privacy in their homes are claimed to have lower stress levels compared to those who lack such comfortable accommodation [45]. A particular case that is mentioned is that people suffering from lung diseases (e.g., in Kazakhstan, around a quarter of children younger than $17 \mathrm{y}$-old have asthma [66]) essentially need access to private outdoor space [55], and balconies and terraces can be considered as an option for those who live in apartment blocks. Natural ventilation can be used to decrease the chance of disease propagation indoors [4]; however, construction developers tend to argue against building balconies to increase the useful area of flats [67]. The availability of outdoor spaces is predicted to become more critical to occupants after this COVID-19 lockdown experience [48]. 


\subsection{Environment}

As staying at home for more extended periods of lockdowns becomes a new lifestyle for many people, it is leading to more extensive consumption of the resources in homes such as energy and water [51] and changes in waste generation mechanisms and profiles at the household level. It also creates an anthropogenic impact on air, water, and soil systems. For instance, several cities have experienced elevated ozone pollution in Central Asia, while NOx concentrations have decreased [68]. It is still uncertain whether the trends of increased consumption of resources will remain established or go back to usual once the pandemic is over. Corresponding to SDG \#6 (Clean Water and Sanitation), SDG \#7 (Affordable and Clean Energy), SDG \#12 (Responsible Consumption and Production), and SDG \#11 (Sustainable Cities and Communities) [61], the present section discusses the post-pandemic development vectors for energy, waste, and water.

\subsubsection{Energy}

Household energy consumption has increased globally during lockdown periods, parallel to people increasing their time spent at home. For example, the UK statistics showed that midday energy consumption had been up to 30\% [46]. Previously, such spikes were present in the mornings, when people were usually preparing for work. In the US, overall household electricity use increased by up to $8 \%$ during lockdowns [47]. There are claims that remote work with the increased use of information and communication technologies (ICT) has brought up to twice the amount of energy utilized [48]. Cooking at home also occurs more frequently during lockdowns, as all the family members stay at home [49]. Consequently, there is a trend of refrigerators consuming more energy due to more frequent access and more food leftovers [69]. Other activities that could increase household energy consumption are entertainment (e.g., television) and laundry (consumption by washing machines) [49]. Therefore, "design-for-pandemic" should include the development of additional, preferably green, energy sources that will be able to sustain a more considerable amount of consumption.

\subsubsection{Waste}

Waste management is a topic with particular importance in the scope of pandemic periods, as it is essential to keep the waste separated to prevent virus transmission, which can survive on different surfaces up to 3-4 days [1]. Face masks are argued to aid in preventing disease transmission [5]; however, due to the increase of using single-use masks and gloves, medical waste has tremendously increased during the pandemic period [50]. Moreover, a need for additional segregation boxes emerged, which would store used protective equipment (masks, gloves, etc.), as they should be separated from domestic waste to minimize the possibility of virus transmission. This may indeed lead to the classification of a new solid waste category [51].

A common practice worldwide is to keep patients with mild symptoms under home quarantine. Therefore, their waste becomes an issue for the waste management services, as it ideally needs to be separated and then sanitized in a similar practice to that of medical waste. It has been observed that recycling practices were suspended to limit the virus spread in many countries [36], showing that the management of recycling and reusing practices are complicated during a pandemic. Finally, online food delivery and single-use packaging are causative factors in increased generation rates of both organic and inorganic domestic wastes [36].

\subsubsection{Water}

Water is an essential resource for healthy households during pandemics, and keeping its use sustainable is vital for humanity. Lockdowns have resulted in increased water consumption in residential buildings [52]. This is linked to the increased amount of time people spend at home during the quarantine. Campaigns promoting washing hands frequently have also added up to increased water use, as it is strongly recommended to wash hands for 40-60 s to sanitize from 
the virus [70]. It is estimated that these recommendations increased water consumption by up to $20 \%$ [53]. Furthermore, for improved disinfection, many people clean their homes and do laundry more frequently. Thus, it is vital to lessen the chances of water scarcity and to sustain resilient water systems. Pandemic-resilient buildings should be ready for surges in water use during lockdowns by having a sufficient amount of accessible water resources and the availability of technologies improving sustainable water consumption.

Management of wastewater is another crucial point to consider. The experience of the SARS virus outbreak in 2003 has raised great concern regarding the elimination of the virus from the feces of infected people that will contaminate wastewater [71]. There is already evidence that SARS-CoV-2 gas been found in hospital canalizations [54] and community wastewater collection sites, and is threatening community sewage lines with contamination [72]. Therefore, proper wastewater management needs proper sanitization and treatment to eliminate the virus to prevent spread.

\subsection{Comfort}

As the social distancing and lockdown measures for virus spread prevention led to an increase in time spent at home, home quarantine experience varied significantly from person to person, mostly depending on their home conditions. The present section reviews (1) reconsideration of personal comfort needs (related to SDG \#3-Good Health and Wellbeing), (2) necessity of residential facilities' living costs retention (related to SDG \#1-No Poverty), and (3) emerging need for local services independency (related to SDG \#11—Sustainable Cities and Communities [61]).

\subsubsection{Personal Comfort}

Basic needs for households are natural light, proper ventilation and air quality, adequate acoustics level (i.e., sufficient sound isolation for multi-story buildings), and comfortable climate (e.g., adequate humidity, heating, and cooling) [4]. Nearly $12 \%$ of the population of OECD countries live in populous households, and a single person over 12 years has less than a room of personal space [39]. For instance, people in Central Asian countries tend to live in large families, exemplified by the fact that more than 3000 families in Kazakhstan have more than seven children [73], and 10\% of Uzbekistani families have five or more children [74]. WHO [56] recommends having separate sanitation facilities in households to eliminate the risk of viruses' propagation. Lack of access to private sanitation facilities complicates the isolation of infected occupants. Crowded housing negates social distancing measures and also worsens comfort during lockdowns due to inadequate privacy.

Due to the coronavirus outbreak, the usage of information technologies has been significantly boosted for a better minimization of human-to-human interaction such as food and medicine deliveries, booking slots to visit a doctor [75], and public services for householders [48]. During as well as after lockdowns, the majority of working-class people, as well as students, have been forced to work or study from home. Even though working and studying at home impels higher standards of home comfort conditions equipped with information and communications Ttchnologies (ICT), only $74 \%$ of households in the Commonwealth of Independent States (CIS) have proper internet access [39]. The use of ICT can be a comfortable option for young generations, but older people are less able to use it effectively. For example, the statistics from Kazakhstan show that only $8 \%$ of people aged over 74 are able to use ICTs [39]. The availability of certain communication services is essential in the case of remote therapies, as due to the pandemic, patients are consulting doctors online. Therefore, sound communication technologies such as high-speed internet with phone connections would likely become a "must" in post-pandemic residential buildings.

\subsubsection{Living Cost}

As a consequence of disturbances in lifestyles in combination with lockdowns, there was an abrupt fall in global economic activity during the pandemic, which later partially recovered. For example, the Asian region has faced an approximately $12 \%$ drop in working hours [39]. Earning losses may lead to 
severe consequences from a worsening of individuals' social status to driving society into increased poverty. For example, the Central Asian countries are mostly developing economies, and they are more subject to the risk of "malnutrition" [39]. For instance, in Kazakhstan, about 2.5 million people have already lost their monthly incomes due to lockdown measures, after which they were paid monthly assistance of around only 100 USD [57] only once. Of OECD countries, 35\% are claimed to have considerable financial risks [39]. It is essential to keep living costs adequate for people being able to survive in such difficult times. Particular focus can be put on adequate retention of the buildings' operational costs by smart systems that enable sustainable use of electricity and water, and people from socially vulnerable categories could be financially supported to pay their utilities [58].

\subsubsection{Local Services}

The quarantine measures effectively prohibited personal transportation for long distances from home [76]. Moreover, public transportation was suspended in most places during lockdowns, and later many people have become scared to use mass transportation options even for short distances [52,77]. People were obliged to get food, medicines, and all other needs near their homes. Moreover, due to the closure of intercity roads and building accessibility during a quarantine, supply chains can get complicated and cause massive disruption, resulting in people raising complaints about scarce reserves of food and medicine supplies. In some instances, people were highly dissatisfied with being entrapped in a residential complex due to cordoning off the building premises due to the isolation of an infected person [59]. This shows that from the very first days of obliged quarantine, the occupants may experience such difficulties.

The pandemic times increased the level of interest in the development of resilient food systems that have relatively short supply paths with self-sufficient local markets, pharmacies, and urban farming technologies [11]. The development of local suppliers also improves the local economy and reduces the chance of virus transmission thanks to shorter travel paths [78].

\section{Current Sustainability Requirements}

Architects and urban planning institutions are one of the first to respond to disasters such as tsunamis, hurricanes, warfare, earthquakes, and bushfires. They are highly involved in the reconstruction of damaged cities or towns after natural disasters. However, it is surprising that the impalpable calamities, such as pandemics, result in the less active involvement of architects and urban planners. The reason might be that understanding of "disaster" is restricted to only physical natural/anthropogenic types of calamities [79].

One way to push the design of buildings into more sustainable and green approaches and solutions is sustainable assessment tools and guides. The three main components of sustainability are environment, society, and economy, which make a foundation for sustainability assessment tools [80]. Typical categories that are included in the sustainability assessment tool of residential buildings are energy, water, indoor and outdoor environments, site consideration, and material input [81]. Awadh (2017) [82] compared the four most popular and widely used sustainability assessment rating systems: The British Building Research Establishment Environmental Assessment Method (BREEAM), Leadership in Energy and Environmental Design (LEED), Global Sustainability Assessment System (GSAS), and Estidama Pearl Rating System. After analyzing all four sustainability assessment rating systems, he concluded that the main priority with the highest weight is given to the energy category in BREEAM, GSAS, and Estidama systems. At the same time, LEED puts into first place the indoor environmental quality category. Among the three major sustainability pillars (environmental, social, and economic), the environmental side is given the most significant attention, while the social pillar is given the least importance in all four sustainability assessment rating systems [82].

Considering the wide range of problems (domestic violence, energy, waste, and water management, food supply, etc.) that have arisen during the COVID-19 pandemic and the inability of current sustainability requirements of residential buildings to tackle those problems, there is a need for 
reconsideration of current sustainability system and its requirements. Sustainability requirements of residential buildings should be adapted into the new reality with COVID-19-like pandemics, which humanity is going to face for the next decades and even centuries.

\section{Major Expected Changes in Sustainability Requirements}

Along with the lessons learned from COVID-19, there are changes in sustainability requirements as well, which can be grouped into the following (summarized in Table 3): (1) health and safety, (2) environment, and (3) comfort.

\subsection{Health and Safety}

During the COVID-19 pandemic, we have witnessed how even advanced health systems of developed countries were being stretched beyond their capacity [83]. During such unexpected situations, it is crucial to ensure the safety of the citizens who have been locked in their homes without an opportunity to visit hospitals, which are outside of their capacities. New innovative technologies, including automotive systems, voice and face recognition, and other artificial intelligence-based smart technologies, could help people to create healthy and safe conditions in our modern shelters [7]. Considering the possibility of virus transmission via the surfaces that were in contact with an infected person, touchless technologies could be beneficial [84,85]. Keycard swiping, voice control, or face recognition technologies will help people to avoid any unnecessary contact with contaminated surfaces [35]. For instance, elevators could be controlled via smartphone as well as blinds and lightings, while doors can be opened automatically using motion sensors or face recognition systems $[17,86]$. Self-cleaning spaces, especially bathrooms in houses and public restrooms in commercial buildings, are an effective solution to sanitize areas without human contact via spraying-down disinfection or applying UV light [86].

Table 3. Summary of expected changes in sustainability requirements of residential buildings.

\begin{tabular}{|c|c|c|c|}
\hline Category & Subcategory & Details & References \\
\hline \multirow{4}{*}{ Health \& Safety } & Smart technologies & $\begin{array}{c}\text { Touchless technologies such as face recognition, voice control, motion sensors, } \\
\text { keycard swiping will help decrease the contact with surfaces, which is one of } \\
\text { the transmission routes of the viruses.Smart technologies would also allow } \\
\text { designing self-cleaning spaces (bathrooms, toilets, etc.). }\end{array}$ & {$[7,17,35,84-86]$} \\
\hline & $\begin{array}{l}\text { Indoor finishing } \\
\text { materials }\end{array}$ & $\begin{array}{l}\text { Copper and its alloys can effectively kill microorganisms and viruses. Steel and } \\
\text { plastic surfaces allow viruses to be active for long durations compared to } \\
\text { copper or cardboard surfaces. However, antimicrobial additive for indoor } \\
\text { finishing materials should be carefully selected due to the risk of equally being } \\
\text { toxic to humans. }\end{array}$ & {$[35,85,87-94]$} \\
\hline & $\begin{array}{l}\text { Green and natural } \\
\text { environment }\end{array}$ & $\begin{array}{l}\text { The addition of green spaces into residential building designs will enhance the } \\
\text { mental health of residents, decreasing stress, anxiety, and depression during } \\
\text { lockdowns. Gardens, where people could grow their own plants, will facilitate } \\
\text { the relaxation of residents and increase their psychological well-being. }\end{array}$ & {$[13,16,35,95-100]$} \\
\hline & $\begin{array}{l}\text { Indoor air quality, } \\
\text { temperature, humidity }\end{array}$ & $\begin{array}{l}\text { Constant air ventilation is essential for maintaining clean indoor air to prevent } \\
\text { the spread of the virus. Furthermore, the proper temperature and humidity of } \\
\text { the air are critical to the health as well as the comfort of the residents. }\end{array}$ & [101-103] \\
\hline \multirow{3}{*}{ Environment } & Energy & $\begin{array}{l}\text { Increased energy consumption due to work from home practices can be } \\
\text { controlled via energy-consuming technologies and smart systems, which } \\
\text { would increase the efficiency at home. }\end{array}$ & {$[47,104,105]$} \\
\hline & Solid waste & $\begin{array}{l}\text { Increased solid waste, especially personal protective equipment such as masks } \\
\text { and gloves, highlighted a need for proper management and disposal of } \\
\text { potentially infected waste. }\end{array}$ & {$[13,31]$} \\
\hline & Wastewater & $\begin{array}{c}\text { Since the virus is able to transmit via human feces that contaminate wastewater, } \\
\text { there is a risk of its transmission via sewage. Proper wastewater management } \\
\text { via additional measures may be needed to avoid the spread of the virus } \\
\text { via wastewater. }\end{array}$ & {$[13,54,56,71,72]$} \\
\hline \multirow{3}{*}{ Comfort } & Housing automation & $\begin{array}{l}\text { Sensors and detectors connected to smart systems would allow us to manage } \\
\text { and control the home more comfortably, faster, and smarter. }\end{array}$ & [13,106-109] \\
\hline & Layout & $\begin{array}{l}\text { With the emerging need to work from home, the layout of the rooms is going to } \\
\text { likely be different, with more attention paid to the design of comfortable, } \\
\text { isolated, and separate workplaces. }\end{array}$ & {$[31,79,110-112]$} \\
\hline & Intimacy & $\begin{array}{c}\text { Difficulties in finding some private space during lockdown will shift new } \\
\text { housing design towards more private spaces, allowing each family member to } \\
\text { have a personal spot at home. }\end{array}$ & {$[33,113,114]$} \\
\hline
\end{tabular}


Proper selection of indoor finishing materials is important for the promotion of a healthy environment in homes. It is known that, depending on the surface material, the virus has different lifetimes. For example, virus on stainless steel or plastic remained virulent for a longer time compared to copper or cardboard [85]. Copper and alloys of copper (e.g., bronze and copper-nickel-zinc alloys) can kill various microorganisms and viruses via disruption of their vital cell functions $[87,88]$. The porosity of the cardboard material plays a beneficial role, since the virus becomes stuck in the fibers and dries out [88]. Other materials close to cardboard in terms of porosity and structure can be potential antimicrobial materials. Additionally, the design of new houses can use antimicrobial materials such as Lapitec®(a mixture of ceramics, quartz, porcelain, and granite) and KrionTM (Alumina Trihydrate mixed with a small amount of high-resistance resins) for bathroom finishes and countertops $[35,93,94]$. Another aseptic material is Richlite, which is already being used for building facades, furniture, wall panels, and countertops as an alternative material for stone and metal due to its high sustainability and durability [35]. Despite the increased promotion of antimicrobial additions in building products, antimicrobial additive usage in coatings and finishing for interior spaces does not guarantee healthier conditions and possibly harms humans and the environment [89-92].

People locked in their homes during quarantine had to spend and do all daily activities, including eating, working, socializing, and leisure time, indoors [115]. Even though quarantining is effective against the spread of the virus, it has a negative psychological effect on mental health combined with a long period of lockdown. Fear of infection, financial crisis, simple boredom, and a decrease in physical activity must be noticed and taken into consideration [116]. Various studies claim that the level of natural, green environment in homes can influence both the physical and mental health of the residents [95]. Nature-friendly design of buildings not only allows the reduction of the influence of rapid urbanization on climate and ecology, but also has a beneficial effect on the health of people of all age groups $[96,97]$. One of the ways to increase the green area in urban environments is the implementation of green roofs.

Moreover, the presence of green spaces results in higher availability of physical and relaxation activities in a natural environment, which also promotes a healthy lifestyle and well-being, as well as decreasing the chance of pathologies like heart diseases, anxiety and depression, skeletal disorders, diabetes, and so on [98]. The most discussed and studied benefit of green spaces is their psychological effect. Greenery helps to reduce stress and mental tiredness; to soften various emotions like anger, depression, and anxiety; and to promote socialization via creating a meeting spot for residents [99]. The views from windows that contain green nature can also positively affect residents' psychological state, reducing stress and accelerating their healing process [13]. Small gardens on the roof or balcony can also improve the mental health of residents [16]. Growing activity, including plants and vegetables, is proven to be satisfactory, increasing physical, psychological, and social well-being [100]. Incorporating elements of nature could be one way to increase the sustainability of the buildings in terms of the mental health of the residents [35].

Air quality and temperature of living spaces are strategic topics for the development of a sustainable building, especially during quarantine times, when everyone is stuck in their homes [101]. Natural ventilation of rooms via window opening, especially during quarantine, to ensure healthy indoor air quality is preferred, rather than mechanical ventilation. Air extractors could be equipped in the rooms without windows (e.g., bathrooms, toilets, closets) with constant cleaning to avoid their contamination with the virus [102]. Along with ventilation, air conditioning and heating systems for a proper microclimate of rooms should be maintained to avoid too-dry air by keeping an appropriate level of indoor humidity [103]. With the help of current technologies, it is possible to create a smart system, which would automatically detect the indoor air quality (temperature, humidity, etc.) and operate the equipment responsible for air quality control. 


\subsection{Environment}

The sanitary condition of the indoor environment is of the utmost importance when people are kept confined in their homes, avoiding the virus [34]. One of the critical factors of safe sanitary conditions is the availability of clean drinkable water and the management of wastewater and solid waste $[13,117]$. The coronavirus is known to be persistent in water and wastewater [118], which means wastewater management needs to be carefully designed considering the possible spread of the virus via wastewater into the environment.

Even though transmission of the virus via wastewater has a low probability, The World Health Organization (WHO) reported that it is possible, especially when aerosolized. It was suggested to further maintain and treat infected wastewater in a well-managed/designed wastewater treatment plants [56]. Additionally, proper plumbing work with sealed bathroom catchments, cranes, and pulverizers with backflow valves in order to avoid the entry of aerosolized wastewater into plumbing or ventilation systems is recommended. This is needed to prevent virus propagation further, as well as for the security of drainage lines and to ensure the safety of family members and people sharing a house. It is better to have a separate bathroom, which can be disinfected at least once a day and kept clean for individuals who are infected or suspected to be infected. For the houses with toilets, which are not connected to centralized sewers, separated on-site treatment systems should be designed [13]. Well-planned and proper wastewater drainage design can decrease the potential risk of wastewater sewages being contaminated with viruses. Due to increased health concerns during the pandemic, the environmental aspect of usage and disposal of personal protective equipment such as masks and gloves lacks proper attention [31]. Some EU and US cities have stopped the operation of waste recycling to prevent a possible spread of the virus among recycling facilities' workers [13]. Organized solid waste management of residential buildings (e.g., additional segregation boxes for medical or possibly infected waste) would prevent potential virus spread as well as keep up the sanitary conditions of the building.

The energy consumption of residential buildings was increased during COVID-19 lockdown due to work from home practices with constant use of electronic devices and other household features [47]. There are a lot of smart ways to decrease and keep under control the residential energy consumption: a smart power strip can sense when the device is not being used and cut off the energy supply automatically, energy monitoring systems may allow seeing where the energy is being wasted most, programmable thermostats enable us to automatically turn on and off the heating only during the time that we need, eco-showerheads decrease the amount of water used for showering, solar chargers enable charging electronic devices using solar energy, and using LED lighting may increase the light comfort and energy savings $[104,105]$. All these technologies could be part of the design of new residential buildings aimed to increase their sustainability in terms of the environment.

\subsection{Comfort}

The COVID-19 pandemic forced most of the population to be trapped in their homes, trying hard to transform their spaces to satisfy various needs at the same time: relaxation, work, physical activity, study, and so on. Unintentionally, our homes were tested for flexibility, pliability, and adaptability [102]. Fast and robust internet connection plays a pivotal role in the design and construction of smart houses and creates necessary comfort for living. It satisfies the different needs of the new household reality, especially the ability to work and study from home while being isolated for an extended period [108,109].

D'alessandro et al. (2020) [13] state that housing automation plays a strategic role in facing the new living environment caused by the COVID-19 pandemic. Innovative computer systems equipped with various detectors and sensors (e.g., motion sensors, thermal detectors, etc.) and remote control via mobile devices (e.g., smartphones, tablets) can enhance the ability of the home to be controlled and managed easier, faster, and smarter. Firstly, the comfort of a house/apartment can be increased by applying remote control and automated regulation of air quality, air conditioning, 
temperature and humidity, blinds, and lights [106,107]. In addition, they can become more secure with the implementation of new technologies like anti-theft systems; automatic opening and closing of windows, doors, and shutters; and fire-prevention systems [13].

Working from home became an everyday activity for many employees due to companies being forced to shift towards remote working. For the majority of companies, it was their first time experiencing online collaboration, operation, and communication from home via virtual communication technologies [111,112]. The major challenges that were faced during being locked down and working from home were staying organized, time management, collaboration, and social interaction [110]. Proper arrangement of the workspace in houses will be given more attention and consideration. The organization of the rooms and layout of the houses is going to change. The working place will be separated and include comfortable furniture, large windows, and blackout curtains. Technical equipment and good sound isolation will be an important feature of a comfortable workplace in a home [31,79].

Intimacy and being able to find a private space are an important part of the social side of the architecture. Open plan living was popular in recent years, offering single, large open space for multifunctional purposes, like kitchens connected with living rooms. However, many people found it difficult to find some private space when the whole family was home [113]. Some flexible building systems, such as Woods Bagot's AD-APT system [114], could gain popularity due to its ability to adapt the layout of the house for different purposes. Thanks to such systems, adjustable walls and screens allow the division of the open space into smaller spaces, such as home office, entertainment area, exercising space, or even bedroom [114]. Additionally, the layout of the housing with small rooms, which are connected to the bigger space via winding corridors, will make people have some private space, at the same time feeling a connection with the rest of the building's community. Since one type of layout design cannot satisfy all people, architectural designs that allow changing the space in different ways can be predominant [33].

\section{Conclusions}

The current COVID-19 pandemic is bringing different changes to society. It is humanity's responsibility to prepare plans and implement necessary actions for future disease outbreaks. Residential buildings are crucial for the health of the population, as they determine social well-being. Homes had critical importance during lockdown periods during which people were required to stay home for infection spread prevention. The nature of this home quarantine experience differed significantly from person to person. This invokes a substantial rethinking of housing to prepare humanity for future possible disease outbreaks.

The present paper addresses a critical question to the community of building sustainability research: "What can we learn from the recent pandemic to modify the building suitability criteria and assessment methods that would promote better sustainable living conditions during such difficult periods affecting entire populations?" The answers to this question will lead to significant changes to the existing methods. We specifically expect that existing building sustainability rating methods that mainly favor "environmental impact" and "energy performance" of buildings will receive a significant shift towards emphasizing "social and health" aspects. It is finally encouraging to see the opportunities that the disruption brings, and the improvements that would be implemented may be financially supported by expected COVID-19 stimulus financing for the building industry as well as existing/upcoming green stimulus packages.

COVID-19 pandemic and lockdown measures have revealed the deficiencies in existing residential buildings in terms of health and safety risks, excess consumption of environmental resources, and lack of personal comfort. The following changes are expected to improve health and safety in houses: widened use of touchless and automotive technologies, selection of finishing materials with regards to viral survivability, and development of green spaces. As a response to environmental needs, sustainable technologies mainly and particularly need to address the issue of improving the increased consumption 
of energy and water. For comfort enhancement, residential houses need to improve communication technologies to use remote services better and use automotive technologies to regulate better comfort parameters: air quality, light, temperature, humidity, and so on.

Future scenarios involving upcoming pandemics cannot be precise, as the nature of the coronavirus as well as its spreading behavior are still being researched. Nevertheless, humanity should be ready for possible repeating outbreaks of COVID as well as other pandemics. Therefore, it is crucial to understand the requirements under pandemic scenarios and design resilient solutions. Future work can proceed in (1) the development of novel building codes and green certificates for the post-pandemic residential buildings and/or (2) the modification of existing codes and certificates considering particular pandemic needs.

Author Contributions: Conceptualization: F.K., M.G., and A.T. (Ali Turkyilmaz); methodology: F.K., M.G., and A.T. (Ali Turkyilmaz): validation: F.K., M.G., and A.T. (Ali Turkyilmaz); investigation: A.T. (Aidana Tleuken) and G.T.; writing-original draft preparation: A.T. (Aidana Tleuken) and G.T.; writing-review and editing: F.K., M.G., and A.T. (Ali Turkyilmaz); supervision: F.K.; project administration: F.K.; funding acquisition: F.K. All authors have read and agreed to the published version of the manuscript.

Funding: This research and the APC was funded by Nazarbayev University Faculty-development competitive research grants, grant number 280720FD1904.

Conflicts of Interest: The authors declare that they have no known competing financial interests or personal relationships that could have appeared to influence the work reported in this paper.

\section{References}

1. Nghiem, L.D.; Morgan, B.; Donner, E.; Short, M.D. The COVID-19 Pandemic: Considerations for the waste and wastewater services sector. Case Stud. Chem. Environ. Eng. 2020, 1, 100006. [CrossRef]

2. Hui, D.S.; Azhar, E.I.; Madani, T.A.; Ntoumi, F.; Kock, R.; Dar, O.; Ippolito, G.; Mchugh, T.D.; Memish, Z.A.; Drosten, C.; et al. The continuing 2019-nCoV epidemic threat of novel coronaviruses to global health-The latest 2019 novel coronavirus outbreak in Wuhan, China. Int. J. Infect. Dis. 2020, 91, 264-266. [CrossRef] [PubMed]

3. Morris, A. Coronavirus Outbreak Is Part of Worldwide Increase in Disease Spread. Available online: https://www.azcentral.com/story/news/local/arizona-health/2020/03/30/coronavirus-covid-19outbreak-part-worldwide-increase-disease-spread/5048560002/ (accessed on 9 September 2020).

4. Eykelbosh, A. COVID-19 Precautions for Multi-Unit Residential Buildings; National Collaborating Centre for Environmental Health: Winnipeg, MB, Canada, 2020.

5. Dietz, L.; Horve, P.F.; Coil, D.A.; Fretz, M.; Eisen, J.A.; Van Den Wymelenberg, K. 2019 Novel Coronavirus (COVID-19) Pandemic: Built Environment Considerations to Reduce Transmission. mSystems 2020. [CrossRef] [PubMed]

6. Harapan, H.; Itoh, N.; Yufika, A.; Winardi, W.; Keam, S.; Te, H.; Megawati, D.; Hayati, Z.; Wagner, A.L.; Mudatsir, M. Coronavirus disease 2019 (COVID-19): A literature review. J. Infect. Public Health 2020, 13, 667-673. [CrossRef] [PubMed]

7. Megahed, N.A.; Ghoneim, E.M. Antivirus-built environment: Lessons learned from Covid-19 Pandemic. Sustain. Cities Soc. 2020, 61, 102350. [CrossRef] [PubMed]

8. Nicola, M.; Alsafi, Z.; Sohrabi, C.; Kerwan, A.; Al-Jabir, A.; Iosifidis, C.; Agha, M.; Agha, R. The socio-economic implications of the coronavirus pandemic (COVID-19): A review. Int. J. Surg. 2020, 78, 185-193. [CrossRef]

9. Filho, W.L.; Brandli, L.L.; Salvia, A.L.; Rayman-Bacchus, L.; Platje, J. COVID-19 and the UN sustainable development goals: Threat to solidarity or an opportunity? Sustainability 2020, 12, 5343. [CrossRef]

10. Aitharaju, R. Digital Transformation and Sustainability: A Post-COVID Impact Analysis of Global Businesses. In Proceedings of the Global Business Trends In View of Lock Down and Role Of Digital Transformation for Sustainability; Indian Institute of Management: Udaipur, India, 2020; pp. 35-38.

11. Blay-Palmer, A.; Carey, R.; Valette, E.; Sanderson, M.R. Post COVID 19 and food pathways to sustainable transformation. Agric. Human Values 2020, 37, 517-519. [CrossRef]

12. Tran, T.; Hoang, A.D.; Nguyen, Y.C.; Nguyen, L.C.; Ta, N.T.; Pham, Q.H.; Pham, C.X.; Le, Q.A.; Dinh, V.H.; Nguyen, T.T. Toward sustainable learning during school suspension: Socioeconomic, occupational aspirations, and learning behavior of vietnamese students during COVID-19. Sustainability 2020, 12, 4195. [CrossRef] 
13. D’alessandro, D.; Gola, M.; Appolloni, L.; Dettori, M.; Fara, G.M.; Rebecchi, A.; Settimo, G.; Capolongo, S. COVID-19 and living space challenge. Well-being and public health recommendations for a healthy, safe, and sustainable housing. Acta Biomed. 2020, 91, 61-75. [CrossRef]

14. UN News. Coronavirus Update: COVID-19 Likely to Cost Economy \$1 Trillion during 2020, Says UN Trade Agency. Available online: https://news.un.org/en/story/2020/03/1059011 (accessed on 13 September 2020).

15. Gracy, B. Digital Transformation: 4 Ways to Plan for the Post-Pandemic Normal. Available online: https://enterprisersproject.com/article/2020/4/digital-transformation-how-plan-post-pandemic (accessed on 13 September 2020).

16. Makhno, S. Life after Coronavirus: How Will the Pandemic Affect Our Homes? Available online: https: //www.dezeen.com/2020/03/25/life-after-coronavirus-impact-homes-design-architecture/ (accessed on 13 September 2020).

17. Wainwright, O. Smart Lifts, Lonely Workers, No Towers or Tourists: Architecture after Coronavirus. Available online: https:/www.theguardian.com/artanddesign/2020/apr/13/smart-lifts-lonely-workers-notowers-architecture-after-covid-19-coronavirus (accessed on 13 September 2020).

18. Dreessen, T. How COVID-19 Will Change the Design of Our Cities. Available online: https://www.obj.ca/ article/sponsored-architects-dca-how-covid-19-will-change-design-our-cities (accessed on 16 August 2020).

19. Zhou, H.; He, S.; Cai, Y.; Wang, M.; Su, S. Social inequalities in neighborhood visual walkability: Using street view imagery and deep learning technologies to facilitate healthy city planning. Sustain. Cities Soc. 2019, 50, 101605. [CrossRef]

20. Molla, R. This Is the End of the Office as We Know It. Available online: https://www.vox.com/recode/2020/ 4/14/21211789/coronavirus-office-space-work-from-home-design-architecture-real-estate (accessed on 13 September 2020).

21. Marr, B. How the COVID-19 Pandemic Is Fast-Tracking Digital Transformation in Companies. Available online: https://www.forbes.com/sites/bernardmarr/2020/03/17/how-the-covid-19-pandemic-is-fast-trackingdigital-transformation-in-companies/\#54281a93a8ee (accessed on 13 September 2020).

22. Smith, R.; Quale, J. Offsite Architecture: Constructing the Future; Taylor \& Francis: Abingdon, UK, 2017.

23. Hatcher, J. Modular Buildings in the Time of Covid-19. Available online: https://smartbuildingsmagazine. com/features/modular-buildings-in-the-time-of-covid-19 (accessed on 15 September 2020).

24. Lubell, S. Commentary: Past Pandemics Changed the Design of Cities. Six Ways COVID-19 Could Do the Same. Available online: https://www.latimes.com/entertainment-arts/story/2020-04-22/coronaviruspandemics-architecture-urban-design (accessed on 15 September 2020).

25. Constable, H. The New Coronavirus Has Spread Rapidly in Cities around the Globe. How Might the Virus Make Us Think Differently about Urban Design in the Future? Available online: https://www.bbc.com/ future/article/20200424-how-do-you-build-a-city-for-a-pandemic (accessed on 7 September 2020).

26. Kashdan, R. Six Ways Urban Spaces May Change Because of Coronavirus. Available online: https: //www.bostonmagazine.com/property/2020/04/30/urban-spaces-coronavirus/ (accessed on 15 September 2020).

27. Lin, F.; Howell-Jones, M. Smart Construction Could Transform Home-Building after COVID-19. Available online: https://www.weforum.org/agenda/2020/08/here-s-how-smart-construction-could-transform-homebuilding-after-covid-19/ (accessed on 13 September 2020).

28. Hoffer, A. How the Coronavirus Is Affecting Home Construction. Available online: https:/www.washingtonpost.com/business/2020/06/11/business-our-new-normal-pandemics-effecthome-construction-market/?arc404=true (accessed on 13 September 2020).

29. Ali, H.M.; Dom, M.M.; Sahrum, M.S. Self-Sufficient Community through the Concepts of Collective Living and Universal Housing. Procedia Soc. Behav. Sci. 2012, 68, 615-627. [CrossRef]

30. Priday, C. Architecture after Coronavirus. Available online: https:/exepose.com/2020/05/05/architectureafter-coronavirus/ (accessed on 7 September 2020).

31. Capolongo, S.; Rebecchi, A.; Buffoli, M.; Appolloni, L.; Signorelli, C.; Fara, G.M.; D’Alessandro, D. COVID-19 and cities: From urban health strategies to the pandemic challenge. A decalogue of public health opportunities. Acta Biomed. 2020, 91, 13-22. [CrossRef] [PubMed]

32. Harrouk, C. Architecture Post COVID-19: The Profession, the Firms, and the Individuals. Available online: https://www.archdaily.com/939534/architecture-post-covid-19-the-profession-the-firms-and-theindividuals (accessed on 13 September 2020). 
33. Wintle, T. COVID-19 and the City: The Future of Pandemic-Proofed Buildings. Available online: https://newseu.cgtn.com/news/2020-07-12/COVID-19-and-the-city-The-future-of-pandemic-proofedbuildings-RCqRHMSn72/index.html (accessed on 13 September 2020).

34. Dettori, M.; Altea, L.; Fracasso, D.; Trogu, F.; Azara, A.; Piana, A.; Arghittu, A.; Saderi, L.; Sotgiu, G.; Castiglia, P. Housing Demand in Urban Areas and Sanitary Requirements of Dwellings in Italy. J. Environ. Public Health 2020, 2020, 7642658. [CrossRef] [PubMed]

35. Lippe-McGrow, J. The Future of Design after COVID-19. Available online: https://www.departures.com/ lifestyle/architecture/architects-predict-future-of-design (accessed on 13 September 2020).

36. Zambrano-Monserrate, M.A.; Ruano, M.A.; Sanchez-Alcalde, L. Indirect effects of COVID-19 on the environment. Sci. Total Environ. 2020, 728. [CrossRef]

37. Bahadursingh, N. 8 Ways COVID-19 Will Change Architecture. Available online: https://architizer.com/blog/ inspiration/industry/covid19-city-design/ (accessed on 14 September 2020).

38. Grant, M.J.; Booth, A. A typology of reviews: An analysis of 14 review types and associated methodologies. Health Inf. Libr. J. 2009, 26, 91-108. [CrossRef]

39. Committee for the Coordination of Statistical Activities. How COVID-19 Is Changing the World: A Statistical Perspective; United Nations Conference on Trade and Development: Geneva, Switzerland, 2020.

40. Moreno, C.; Wykes, T.; Galderisi, S.; Nordentoft, M.; Crossley, N.; Jones, N.; Cannon, M.; Correll, C.U.; Byrne, L.; Carr, S.; et al. How mental health care should change as a consequence of the COVID-19 Pandemic. Lancet Psychiatry 2020, 7, 813-824. [CrossRef]

41. UNFPA Kazakhstan. UNFPA Kazakhstan|People in Kazakhstan Report More Cases of Domestic Violence during Quarantine. Available online: https://kazakhstan.unfpa.org/en/news/people-kazakhstan-reportmore-cases-domestic-violence-during-quarantine (accessed on 6 September 2020).

42. Akisheva, B.A. Women Face-To-Face with Domestic Abuse during COVID-19; Central Asia Program: Washington, DC, USA, 2020.

43. Pannier, B.; Tahir, M. Majlis Podcast: With Coronavirus, Domestic Violence in Central Asia Has Gotten Much Worse. Available online: https://www.rferl.org/a/majlis-podcast-with-coronavirus-domestic-violence-incentral-asia-has-gotten-much-worse/30707018.html (accessed on 6 September 2020).

44. Taub, A. How Domestic Abuse Has Risen Worldwide since Coronavirus-The New York Times. Available online: https://www.nytimes.com/2020/04/06/world/coronavirus-domestic-violence.html (accessed on 6 September 2020).

45. Clair, A. Homes, Health, and COVID-19: How Poor Housing Adds to the Hardship of the Coronavirus Crisis_Social Market Foundation. Available online: https://www.smf.co.uk/commentary_podcasts/homeshealth-and-covid-19-how-poor-housing-adds-to-the-hardship-of-the-coronavirus-crisis/ (accessed on 9 September 2020).

46. BBC. Coronavirus: Domestic Electricity Use up during Day as Nation Works from Home-BBC News. Available online: https://www.bbc.com/news/technology-52331534 (accessed on 7 September 2020).

47. Abergel, T.; Delmastro, C.; Kevin, L. Buildings-The Covid-19 Crisis and Clean Energy Progress; International Energy Agency: Paris, France, 2020.

48. Freire-González, J.; Font Vivanco, D. Pandemics and the Environmental Rebound Effect: Reflections from COVID-19. Environ. Resour. Econ. 2020, 1-4. [CrossRef]

49. Edomah, N.; Ndulue, G. Energy transition in a lockdown: An analysis of the impact of COVID-19 on changes in electricity demand in Lagos Nigeria. Glob. Transit. 2020, 2, 127-137. [CrossRef]

50. Eroğlu, H. Effects of Covid-19 outbreak on environment and renewable energy sector. Environ. Dev. Sustain. 2020. [CrossRef]

51. Pinheiro, M.D.; Luís, N.C. COVID-19 could leverage a sustainable built environment. Sustainability 2020, 12, 5863. [CrossRef]

52. Kalbusch, A.; Henning, E.; Brikalski, M.P.; de Luca, F.V.; Konrath, A.C. Impact of coronavirus (COVID-19) spread-prevention actions on urban water consumption. Resour. Conserv. Recycl. 2020, 163, 105098. [CrossRef] [PubMed]

53. Mukherjee, A.; Babu, S.S.; Ghosh, S. Thinking about water and air to attain Sustainable Development Goals during times of COVID-19 Pandemic. J. Earth Syst. Sci. 2020, 129. [CrossRef] 
54. Wang, J.; Feng, H.; Zhang, S.; Ni, Z.; Ni, L.; Chen, Y.; Zhuo, L.; Zhong, Z.; Qu, T. SARS-CoV-2 RNA detection of hospital isolation wards hygiene monitoring during the Coronavirus Disease 2019 outbreak in a Chinese hospital. Int. J. Infect. Dis. 2020, 94, 103-106. [CrossRef]

55. Charara, S. Our Terrible Housing Stock Is Making Lockdown Life Even Worse|WIRED UK. Available online: https://www.wired.co.uk/article/coronavirus-architecture-isolation-home-design (accessed on 10 September 2020).

56. WHO. Water, Sanitation, Hygiene, and Waste Management for SARS-CoV-2, the Virus That Causes COVID-19; WHO: Geneva, Switzerland, 2020.

57. Inform.kz. 42500: Более2,6 МлнГражданПодали Заявки на ПолучениеВыплаты. Available online: https://www.inform.kz/ru/42500-bolee-2-6-mln-grazhdan-podali-zayavki-na-poluchenie-vyplaty_ a3690014 (accessed on 10 September 2020).

58. Tikhonova, Y. КоммунальнаяПомощь. Available online: https:/time.kz/articles/territory/2020/05/06/ kommunalnaya-pomoshh (accessed on 10 September 2020).

59. Mediazona.ca. Общество ЗакрытыхПодъездов. ЗапискиАлматинца, Попавшего подПринудительный Карантин. Available online: https://mediazona.ca/article/2020/04/06/covid-19-diary (accessed on 5September 2020).

60. Google News Coronavirus (COVID-19). Available online: https://news.google.com/covid19/map?hl=enUS\&gl=US\&ceid=US\%3Aen (accessed on 18 September 2020).

61. UN. \#Envision2030: 17 Goals to Transform the World for Persons with Disabilities|United Nations Enable. Available online: https://www.un.org/development/desa/disabilities/envision2030.html (accessed on 18 September 2020).

62. Chinazzi, M.; Davis, J.T.; Ajelli, M.; Gioannini, C.; Litvinova, M.; Merler, S.; y Piontti, A.P.; Mu, K.; Rossi, L.; Sun, K.; et al. The effect of travel restrictions on the spread of the 2019 novel coronavirus (COVID-19) outbreak. Science 2020, 368, 395-400. [CrossRef]

63. Tengrinews.kz. 4 Подъезда в Разных ЖКВзяты на Карантин в Нур-Султане: 03 Мая2020, 10:25-Новости на Tengrinews.kz. Available online: https://tengrinews.kz/kazakhstan_news/4-podyezda-vraznyih-jk-vzyatyi-na-karantin-v-nur-sultane-400956/ (accessed on 5 September 2020).

64. Nur.kz. фото с Заваренной ДверьюПодъезда из-за Карантина Объяснили вАкиматеАктау-НовостиМаil.ru. Available online: https://news.mail.ru/society/41249587/ (accessed on 5 September 2020).

65. WHO. Q\&A: Violence against Women during COVID-19. Available online: https://www.who.int/emergencies/ diseases/novel-coronavirus-2019/question-and-answers-hub/q-a-detail/violence-against-women-duringcovid-19?gclid=EAIaIQobChMIuqv_qr7U6wIVAiF7Ch0YWAkmEAAYASAAEgI4tfD_BwE (accessed on 6 September 2020).

66. Forbes KZ. Более100 Тыс. Человек БолеютАстмой в Казахстане-Новости-Forbes Kazakhstan. Available online: https://forbes.kz/news/2019/12/10/newsid_214560 (accessed on 10 September 2020).

67. Kachalova, N. Самоизоляция Изменила Ценность Балконов дляГорожан|Курсив-Деловые Новости Казахстана. Available online: https://kursiv.kz/news/obschestvo/2020-05/samoizolyaciya-izmenila-cennostbalkonov-dlya-gorozhan (accessed on 10 September 2020).

68. Kerimray, A.; Baimatova, N.; Ibragimova, O.P.; Bukenov, B.; Kenessov, B.; Plotitsyn, P.; Karaca, F. Assessing air quality changes in large cities during COVID-19 lockdowns: The impacts of traffic-free urban conditions in Almaty, Kazakhstan. Sci. Total Environ. 2020, 730, 139179. [CrossRef]

69. Save On Energy Team. Has Springtime Quarantine Affected Your Energy Consumption?|SaveOnEnergyß. Available online: https://www.saveonenergy.com/learning-center/post/springtime-quarantine-affected-yourenergy-consumption/ (accessed on 7 September 2020).

70. UNICEF. Everything You Need to Know about Washing Your Hands to Protect against Coronavirus (COVID-19)|UNICEF Kazakhstan. Available online: https:/www.unicef.org/kazakhstan/en/stories/ everything-you-need-know-about-washing-your-hands-protect-against-coronavirus-covid-19 (accessed on 16 September 2020).

71. Cyranoski, D.; Abbott, A. Apartment complex holds clues to pandemic potential of SARS. Nature 2003, 423, 3-4. [CrossRef]

72. Lodder, W.; de Roda Husman, A.M. SARS-CoV-2 in wastewater: Potential health risk, but also data source. Lancet Gastroenterol. Hepatol. 2020, 5, 533-534. [CrossRef] 
73. 24.kz. С Начала 2020 Года Более340 Тыс. МногодетныхСемей НачнутПолучать НовоеГоспособие-Новости Казахстана и Мира на Сегодня. Available online: https: //24.kz/ru/news/social/item/348506-s-nachala-2020-goda-bolee-340-tys-mnogodetnykh-semej-nachnutpoluchat-novoe-gosposobie (accessed on 10 September 2020).

74. UZ Sputniknews. Опрос: узбекистанцы рассказали, сколько детей должно быть в семье. Available online: https://uz.sputniknews.ru/society/20170601/5535950/uzbeki-o-semie.html (accessed on 10 September 2020).

75. E-gov.kz. Прикрепление кПоликлинике в Казахстане|ЭлектронноеПравительство Республики Казахстан. Available online: https://egov.kz/cms/ru/articles/health_care/2Fvybor_polikliniki (accessed on 11 September 2020).

76. Romahkina, S. Казахстан на Карантине-Аналитический Интернет-ЖурналVласть. Available online: https://vlast.kz/obsshestvo/38571-kazahstan-na-karantine.html (accessed on 11 September 2020).

77. Bobylev, S.N. Environmental consequences of COVID-19 on the global and Russian economics. Popul. Econ. 2020, 4, 43-48. [CrossRef]

78. Sarkis, J.; Cohen, M.J.; Dewick, P.; Schröder, P. A brave new world: Lessons from the COVID-19 Pandemic for transitioning to sustainable supply and production. Resour. Conserv. Recycl. 2020, 159. [CrossRef]

79. Allam, Z.; Jones, D.S. Pandemic stricken cities on lockdown. Where are our planning and design professionals [now, then and into the future]? Land Use Policy 2020, 97, 104805. [CrossRef] [PubMed]

80. United Nations General Assembly. 2005 World Summit Outcome; UN General Assembly: New York, NY, USA, 2005.

81. Ardda, N.; Mateus, R.; Bragança, L. Methodology to identify and prioritise the social aspects to be considered in the design of more sustainable residential buildings-Application to a developing country. Buildings 2018, 8, 130. [CrossRef]

82. Awadh, O. Sustainability and green building rating systems: LEED, BREEAM, GSAS and Estidama critical analysis. J. Build. Eng. 2017, 11, 25-29. [CrossRef]

83. Cavallo, J.J.; Donoho, D.A.; Forman, H.P. Hospital Capacity and Operations in the Coronavirus Disease 2019 (COVID-19) Pandemic-Planning for the Nth Patient. JAMA Health Forum 2020, 1. [CrossRef]

84. Marshall, W. Can COVID-19 (Coronavirus) Spread through Food, Water, Surfaces and Pets?-Mayo Clinic. Available online: https://www.mayoclinic.org/diseases-conditions/coronavirus/expert-answers/cancoronavirus-spread-food-water/faq-20485479 (accessed on 16 September 2020).

85. Van Doremalen, N.; Bushmaker, T.; Morris, D.H.; Holbrook, M.G.; Gamble, A.; Williamson, B.N.; Tamin, A.; Harcourt, J.L.; Thornburg, N.J.; Gerber, S.I.; et al. Aerosol and surface stability of SARS-CoV-2 as compared with SARS-CoV-1. N. Engl. J. Med. 2020, 382, 1564-1567. [CrossRef] [PubMed]

86. Stambol Touchless Technology in the Wake of COVID-19. Available online: https://www.stambol.com/2020/ 05/11/touchless-technology-in-the-wake-of-covid-19/ (accessed on 19 September 2020).

87. Spolidoro, B. Healthy Buildings: How Architecture Can Defend Us from COVID-19. Available online: https://www.workdesign.com/2020/05/healthy-buildings-how-architecture-can-defend-us-fromcovid-19/ (accessed on 19 September 2020).

88. Brownell, B. Materials and Coatings That Reduce Surface Transmission of Bacteria and Viruses. Available online: https://www.architectmagazine.com/technology/materials-and-coatings-that-reducesurface-transmission-of-bacteria-and-viruses_o (accessed on 19 September 2020).

89. Hounsell, D. Can Antimicrobials Added to Products Prevent COVID-19? Available online: https://www.facilitiesnet.com/facilitiesmanagement/tip/Can-Antimicrobials-Added-to-Products-PreventCOVID-19--46366 (accessed on 19 September 2020).

90. Ehrlich, B. Antimicrobials in Building Products: The COVID-19 Edition. Available online: https://www. buildinggreen.com/product-review/antimicrobials-building-products-covid-19-edition (accessed on 19 September 2020).

91. Healthy Building Network. Do Antimicrobial Building Products Protect against COVID-19? Healthy Building Network: Washington, DC, USA, 2020.

92. Walsh, B.; Stephens, B.; Dickinson, M.; Richter, M.; Stamm, R.; McGrath, T. Understanding Antimicrobial Ingredients in Building Materials. Perkins Will 2020. [CrossRef]

93. County Stone. Everything You Need to Know about Lapitec. Available online: https://www. countystonegranite.co.uk/blog/inspiration/everything-need-know-lapitec/ (accessed on 24 September 2020). 
94. KRION. What Is KrionTM? A Material for Unlimited Surfaces. Available online: https://www.krion.com/en/ what-is-krion (accessed on 24 September 2020).

95. Ruijsbroek, A.; Droomers, M.; Kruize, H.; Van Kempen, E.; Gidlow, C.J.; Hurst, G.; Andrusaityte, S.; Nieuwenhuijsen, M.J.; Maas, J.; Hardyns, W.; et al. Does the health impact of exposure to neighbourhood green space differ between population groups? An explorative study in four European cities. Int. J. Environ. Res. Public Health 2017, 14, 618. [CrossRef]

96. van den Berg, A.E.; Maas, J.; Verheij, R.A.; Groenewegen, P.P. Green space as a buffer between stressful life events and health. Soc. Sci. Med. 2010, 70, 1203-1210. [CrossRef]

97. Beyer, K.M.M.; Kaltenbach, A.; Szabo, A.; Bogar, S.; Javier Nieto, F.; Malecki, K.M. Exposure to neighborhood green space and mental health: Evidence from the survey of the health of wisconsin. Int. J. Environ. Res. Public Health 2014, 11, 3453-3472. [CrossRef]

98. Maas, J.; Verheij, R.A.; De Vries, S.; Spreeuwenberg, P.; Schellevis, F.G.; Groenewegen, P.P. Morbidity is related to a green living environment. J. Epidemiol. Commun. Health 2009, 63, 967-973. [CrossRef]

99. Cohen-Cline, H.; Turkheimer, E.; Duncan, G.E. Access to green space, physical activity and mental health: A twin study. J. Epidemiol. Commun. Health 2015, 69, 523-529. [CrossRef] [PubMed]

100. Soga, M.; Gaston, K.J.; Yamaura, Y. Gardening is beneficial for health: A meta-analysis. Prev. Med. Rep. 2017, 5, 92-99. [CrossRef] [PubMed]

101. Settimo, G. Residential indoor air quality: Significant parameters in light of the new trends. Ig. Sanita Pubbl. 2012, 68, 136-138. [PubMed]

102. Settimo, G.; Bertinato, L.; Bonadonna, L.; D’Ancona, P.; Santarsiero, A.; Soggiu, M.E. Indicazioni ad Interim per la Prevenzione e Gestione degli Ambienti Indoor in Relazione alla Trasmissione Dell'infezione da Virus SARS-CoV-2; Istituto Superiore di Sanità: Rome, Italy, 2020.

103. Signorelli, C.; Capolongo, S.; Buffoli, M.; Capasso, L.; Faggioli, A.; Moscato, U.; Oberti, I.; Petronio, M.G.; D'Alessandro, D. Italian Society of Hygiene (SItI) recommendations for a healthy, safe and sustainable housing. Epidemiol. Prev. 2016, 40, 265-270. [CrossRef]

104. Constellation Energy-Saving Strategies for Smart Homes. Available online: https://blog.constellation.com/ 2019/01/22/smart-home-energy-saving-strategies/ (accessed on 23 September 2020).

105. Ampower. Top 7 New Energy Saving Technology for Your Home. Available online: https://www.ampoweruk. com/2019/07/16/top-7-new-energy-saving-technology-for-your-home (accessed on 23 September 2020).

106. Marlin, C. How COVID-19 Will Change the Way We Design Our Homes. Available online: https://www. weforum.org/agenda/2020/08/how-covid-19-will-change-what-we-call-home-ddfe95b686/ (accessed on 17 September 2020).

107. Jameson, M. 15 Ways Homes Will Change Post-COVID-19. Available online: https://www.mercurynews. com/2020/06/04/15-ways-homes-will-change-post-covid-19/ (accessed on 17 September 2020).

108. D'Alessandro, D.; Raffo, M. Adapting the answers to new problems of living in a changing society. Ann. Ig. Med. Prev. Comunità 2011, 23, 267-274.

109. Capasso, L.; Gaeta, M.; Appolloni, L.; D'Alessandro, D. Health inequalities and inadequate housing: The case of exceptions to hygienic requirements for dwellings in Italy. Ann. Ig. 2017, 29, 323-331. [CrossRef]

110. Stephens, N. 6 Biggest Challenges of Working from Home. Available online: https://www.vault.com/blogs/ workplace-issues/challenges-of-working-from-home (accessed on 22 September 2020).

111. Parungao, A. The Future of Remote Work after COVID-19: 3 Common Predictions. Available online: https://www.ekoapp.com/blog/the-future-of-remote-work-after-covid-19-3-common-predictions (accessed on 22 September 2020).

112. Boland, B.; De Smet, A.; Palter, R.; Sanghvi, A. Reimagining the Office and Work Life after COVID-19. Available online: https://www.mckinsey.com/business-functions/organization/our-insights/reimagining-theoffice-and-work-life-after-covid-19\# (accessed on 22 September 2020).

113. Hipwood, T. The End of Open-Plan Living? How Covid-19 Is Changing Our Homes. Available online: https://www.fastcompany.com/90515499/the-end-of-open-plan-living-how-covid-19-is-changingour-homes (accessed on 24 September 2020).

114. Bahadursingh, N. 6 Ways COVID-19 Will Change Home Design. Available online: https://architizer.com/ blog/inspiration/industry/covid-19-home-design/ (accessed on 24 September 2020).

115. Rubin, G.J.; Wessely, S. The psychological effects of quarantining a city. BMJ 2020, 368. [CrossRef] 
116. Amerio, A.; Brambilla, A.; Morganti, A.; Aguglia, A.; Bianchi, D.; Santi, F.; Costantini, L.; Odone, A.; Costanza, A.; Signorelli, C.; et al. Covid-19 lockdown: Housing built environment's effects on mental health. Int. J. Environ. Res. Public Health 2020, 17, 5973. [CrossRef]

117. La Rosa, G.; Bonadonna, L.; Lucentini, L.; Kenmoe, S.; Suffredini, E. Coronavirus in water environments: Occurrence, persistence and concentration methods-A scoping review. Water Res. 2020, 179, 115899. [CrossRef]

118. Gundy, P.M.; Gerba, C.P.; Pepper, I.L. Survival of Coronaviruses in Water and Wastewater. Food Environ. Virol. 2009, 1, 10-14. [CrossRef]

Publisher's Note: MDPI stays neutral with regard to jurisdictional claims in published maps and institutional affiliations.

(C) 2020 by the authors. Licensee MDPI, Basel, Switzerland. This article is an open access article distributed under the terms and conditions of the Creative Commons Attribution (CC BY) license (http://creativecommons.org/licenses/by/4.0/). 